RÉKASINÉ ADAMKó Adrienn

DOI: 10.15170/DIKE.2018.02.01.06

$\mathrm{PhD}$-jelölt

Jogi előadó

Magyar Országos Közjegyzői Kamara Jogi Iroda

\title{
Az örökbefogadás Magyarországon 1946 előtt és az örökbefogadás gyakorlata Baranyában
}

\section{The Adoption in Hungary before 1946 and the Practice of Adoption in Baranya County}

The legal institution of adoption had several aims to achieve in the course of time: appointment of an heir, transfer of name, title and foundation of family. At the time of world wars except for the appointment of an heir the most important financial and moral object of adoption was to insure family for the orphan children whose fathers did not come back from war and whose mothers were not able to bring them up. From 1946 the adoption was one of the instruments of legitimization by giving opportunity for children born out of marriage to get an equal legal status to the children born in family. In my study I describe the legal status of children born out of family in Hungary according to the Draft of the first Civil Code (1928) and through the instrument of legitimization in the Statute of 1946. My essay is based on the records of the Hungarian National Archive in Baranya County and the documents found in Pécs City Chancery. During my research I examined 118 adoptions in the related contracts and reports.

Keywords: codification, status of children born out offamily, status of children born in marriage, adoption, contract of adoption, appointment of an heir, legitimization

\section{Az örökbefogadás célja}

A magyar örökbefogadás szó nyíltan utal az örökbefogadott gyermek rokonná tétele mellett arra is, hogy a befogadás az örökössé tételt tűzte ki célul. ${ }^{\text {A }}$ polgári kor előtt az egyenes ági leszármazottal nem rendelkezők elsősorban törvényes örökösről kívántak gondoskodni, hogy biztosítsák a család nevének fennmaradását és rendezzék vagyonuk sorsát a haláluk utáni időre. Azoknál a társadalmi rétegekné (parasztok és iparosok), ahol a család illetve a háztartás a termelőmunka kereteként is szolgált, a gyermeki munkaerőnek is meghatározó szerepe volt, és ez a szempont természetesen érvényesült az örökbefogadás vonatkozásában is. Gyermektelen családok általában többgyermekes testvéreiktől vagy a közeli rokonság körében leltek örökbefogadásra alkalmas kiskorúra vagy nagykorúra. Alkalmas rokongyerek híján számításba jöhetett árva, a századfordulótól - az állami gyermekmenhelyek alapításától kezdve - lelencházi gyermek is. Jómódú család esetében a munkáskéz biztosítása céljából két-három gyermeket is örökbe fogadtak. A belterjes, munkaerőigényes gazdálkodást folytató falvakban, a tanyai gazdálkodásban is előnyt jelentett a családbeli

\footnotetext{
${ }^{1}$ BACsó, Az örökbefogadás 609-616.
} 
olcsó munkaerő, amely az örökség vagy legalább a kiházasítás reményében szorgalmas munkával gyarapította a családi vagyont. ${ }^{2}$

\section{A házasságon kívüli gyermek jogállása és örökbefogadása Magyarország Magánjogi Törvénykönyvének javaslatában}

Ahhoz, hogy az örökbefogadás jogintézményének az előbbiekben vázolt céljain túli jelentőségét is szemléltetni tudjuk, szükséges, hogy bemutassuk a házasságon kívül született gyermekek jogállását a Magánjogi Törvénykönyv 1928-ban országgyúlés elé terjesztett javaslatában (Mtj.) valamint a házasságon kívül született gyermek jogállásáról szóló 1946. évi XXIX. törvénycikkben, melyekben az örökbefogadás a törvénytelen gyermek törvényesítésének egyik eszközeként szolgált.

A pártállami korszak szakirodalmában „kiæsákmányolónak” nevezett társadalmak jogi rendezésén végigvonult a nem házasságból született gyermekek különböző csoportjainak megkülönböztetése, majd ennek eltörlése. Ezek az ún. kizsákmányoló társadalmak, azaz a polgári liberális államok társadalma a nem házasságból született gyermeket azzal, hogy az apával jogi kapcsolatba hozta, olyanná tette - legalábbis bizonyos vonatkozásban - mintha az apa házasságából született volna. Ezért döntő fontosságot tulajdonítottak annak, hogy vajon a vérszerinti szülők a fogantatáskor vagy legalább a fogantatás és a szülés közti időben köthettek-e volna egymással házasságot. ${ }^{3} \mathrm{Ha}$ igen, akkor a gyermek a természetes utód javítható helyzetébe került (naturalis), ha nem, akkor törvénytelen volt (spurius). Különbséget tettek abban is, hogy a házasságkötésnek miben állott az akadálya. Ha az akadály valamelyik vérszerinti szülő fennálló házassága, vagy vérszerinti szülők rokonsága volt, a gyermek - mint aki házasságtörésből (adulterinus) vagy vérfertőzésből (incestuosus) származott - még a nem házasságból született gyermekek sorában is hátrányos megkülönböztetést szenvedett, és el volt zárva családi jogállása orvoslásának bizonyos eszközeitől.

A patriarchális családi rendben az anya és a nem házasságból született gyermeke közti kapcsolat elismerésének akadályát képezte, hogy a gyermek csak egy család tagjává válhatott és ez a család az apa családja volt. Az apa családjába azonban csak az a gyermek kerülhetett, aki az apa feleségétől született (mater semper certa). Ha tehát az anya nem élt házasságban, a gyermeknek csak az anyával és annak rokonaival lehetett volna családi kapcsolata, csak hogy ez a családi kapcsolat vérségi köteléken alapuló cognat kapcsolat - kezdetben minden jogi jelentőséget nélkülözött. Minthogy a nő ebben a rendben finis familiae suae, jogi leszármazói, vérségi jogutódai nincsenek, nem ilyenek a gyermekei sem. A nem házasságból született gyermek ebben az időben - családjogi vonatkozásban - jog nélküli (filius nullius). A helyzetet az enyhítette, hogy a valóságos apának meg volt a lehetôsége arra, hogy a nem házasságból származó gyermekének sorsáról gondoskodva bármit is juttasson, ôt akár a saját családjának teljes jogú tagjává tegye. ${ }^{4}$

\footnotetext{
${ }^{2}$ KŐRÖS (szerk.), A családjog kézikönyve 445-446.; WEISS, Az örökbefogadás néhány társadalmi és jogi kérdése 180.

${ }^{3}$ NiZSALOVSZKY, A család jogi rendjének alapjai 165.

${ }^{4}$ NizSALOVszKY, A család jogi rendjének alapjai 165.
} 
„Akik törvénytelen ágyból származnak, a vérség javaiban, díszeiben nem részesülnek; nevet, nemességet, cimet, örökséget nemzöík után nem nyernek." - foglalta össze régi jogunk álláspontját Frank Ignác. ${ }^{5}$ Magyarországon az 1919 és 1938 közötti években átlagban 18.847 gyermek született házasságon kívül és a házasságon kívül születettek számaránya az összes születésekhez viszonyítva átlagosan 8,9\%-ot tett ki. Mindez körülbelül 500.000 magyar gyermeket érintett. ${ }^{6}$

Köztudomású volt, hogy a házasságon kívül született gyermek sorsa sokkal mostohább volt, mint a házasságban született gyermeké. A házasságon kívül született gyermekkel az atyja rendszerint nem törődött, nem érezte annak sorsáért magát felelősnek. Az ilyen gyermek vélelmezett atyjától csak tartást követelhetett, annak rokonaival szemben semmiféle joga nem volt, többnyire az anyja családja is szégyellte. A házasságon kívüli szülés a nőt szégyenbe és gyakran nyomorba is döntötte. A gyermek a hiányos gondozás és táplálkozás következtében könnyebben lett a különböző gyermekbetegségek áldozata, mint a házasságból született társai. ${ }^{7}$ Ezt támasztja alá az az adat, hogy Budapesten 1919-től 1938-ig a házasságból született gyermekek 9,8\%-a, a házasságon kívül született gyermekek 21,6\%-a halt meg egyéves korának betöltése előtt. A házasságon kívül született gyermekeket játszótársaik többnyire kicsúfolták, az iskolában rádöbbentek, hogy még a nevüket is másként kapták, mint társaik. A társadalom nem volt hajlandó őket teljes értékú tagjának elfogadni, lenézte, másodrendű emberként kezelte őket, akik így testileg, lelkileg „,betegen” nőttek fel, közülük aránytalanul sokan követtek el fiatalkorukban bűncselekményt. ${ }^{8}$

A magyar jogtörténet egészen a 19. századig a házasságon kívül született gyermek jogállására vonatkozóan igen kevés adatot ismer. Ennek oka az, hogy a polgári törvénykezési rendtartás tárgyában meghozott 1868. évi LIV. törvénycikk hatálybalépéséig a származás törvényessége kérdésében a bíráskodás az egyházi bíróságok hatáskörébe tartozott. Az egyházi bíróságok a kánonjogot (illetve a felekezeti egyházjogot) alkalmazták, amely a házasság intézményének védelme érdekében a házasságból és a házasságon kívül történt születés között éles megkülönböztetést tett. A kánonjog hatása alatt került be jogunkba az utólagos házassággal való törvényesítés intézménye, a vélt (putativ) házasságból születettek törvényes származásának elismerése, a házasság alatt, valamint annak megszủnése után bizonyos időn belül született gyermek törvényes származásának vélelme, a királyi kegyelemmel való törvényesítés, valamint az örökbefogadás. ${ }^{9}$ (Ezek közül bővebben az örökbefogadás jogintézményét ismertetem a későbbi fejezetekben).

Az Mtj. kimondta, hogy a házasságon kívüli gyermek a törvény szerint rokona anyjának és anyja rokonainak. Ezzel ellentétben törvényes származásból rokonság keletkezett mind az atyai, mind az anyai ágon. ${ }^{10} \mathrm{Az}$ Mtj. tehát a házasságon kívül született gyermeket kizárólag anyja családja tagjának tekintette, közte, anyja és anyai rokonai között rokoni és öröklési kapcsolat fennállását elismerte, azonban a házasságon kívül született gyermek és atyja, valamint annak rokonai között

\footnotetext{
${ }^{5}$ Frank Ignác (Nagykároly, 1788. március 24. - Bécs, 1850. március 4.) jogász, királyi tanácsos, egyetemi professzor, a Magyar Tudományos Akadémia levelező tagja (1847), a magánjog_művelője, a német történeti jogi iskola hazai követője. Lásd hozzá HERGER, A modern magyar házassági vagyonjog 32.

${ }^{6}$ Indokolás 1946

${ }^{7}$ Indokolás 1946

${ }^{8}$ Indokolás 1946

${ }^{9}$ Indokolás 1946

${ }^{10} \mathrm{Mtj}$. 174. $\mathrm{S}$
} 
fennálló rokoni és öröklési kapcsolat elismerésétől - a tradicionális joghoz hasonlóan - továbbra is mereven elzárkózott. ${ }^{11}$

Amennyiben a házasságon kívüli gyermek atyja és anyja egymással házasságot kötött, az utólagos házasságkötéssel mindkét szülőjének törvényes gyermekévé lett. ${ }^{12}$ Törvényessé lett a házasságon kívüli gyermek akkor is, ha a szülei közt kötött házasság érvénytelenné vált, kivéve, ha a házasság egyenesági vérrokonság, testvéri viszony vagy korábban kötött házasság miatt semmissé lett és erről a házasság megkötésekor mind a két házasulónak tudomása volt. A király a házasságon kívüli gyermeket kérelemre kegyelemből törvényesíthette, kivéve, ha atyja és anyja egyenes ági vérrokonság vagy testvéri viszony miatt egymással házasságot nem köthetett. ${ }^{13}$

A házasságon kívüli gyermek jogállása anyjával és anyja rokonaival szemben ugyanaz volt, mint a törvényes gyermeké, atyjával szemben viszont a törvényben meghatározott jogok illették meg. ${ }^{14}$

A házasságon kívüli gyermek atyjának azt kellett tekinteni, aki az anyával a gyermek fogantatásának idejében nemileg érintkezett, kivéve, ha a körülmények szerint nyilvánvalóan lehetetlen, hogy a gyermek ettől a férfitôl származott, vagy ha az anya a fogantatás idejében oly feslett életet élt, hogy a nemi érintkezést több férfival keresetképpen vagy a női szeméremérzetet botrányosan sértő módon űzte. ${ }^{15}$

A házasságon kívül született gyermeket atyja csak eltartani volt köteles tizenhatodik életévének betöltéséig, vagyoni és kereseti viszonyaihoz képest mindazzal ellátni, ami a gyermeknek anyja társadalmi állásához mért megélhetéséhez és e társadalmi állásnak megfelelő nevelése és önálló keresetre képesítő tanítása költségére szükséges. ${ }^{16}$ A házasságon kívüli gyermek atyja volt köteles megtéríteni az anyának a szüléssel járó költséget, valamint azt a költséget, amibe az anyának a szülés előtti két héten és a szülés után négy héten át társadalmi állásához és az atya vagyoni és kereseti viszonyaihoz mért eltartása került. ${ }^{17}$

A házasságon kívüli gyermek a törvényes gyermekkel szemben nem volt jogosult atyja családnevének viselésére, így anyja családi nevét volt köteles viselni. ${ }^{18}$

A szülői hatalom kérdését szintén differenciált módon szabályozta a törvény, kimondta, hogy a törvényes gyermek felett mindkét szülőnek, házasságon kívüli gyermek felett csak az anyának van szülői hatalma. ${ }^{19} \mathrm{Ha}$ a házasságon kívüli gyermek anyja kiskorú volt, addig szülői hatalma kiskorúsága miatt szünetelt, csak a szülői gondviselés jogát gyakorolhatta, s e tekintetben mellette a gyermek gyámját a tanácsadó jogállása illette meg. ${ }^{20}$

A házasságon kívüli gyermek örökösödési jogát illetően az Mtj. kimondta, hogy kivételesen - az államkincstárt megelőzve - az örökhagyó volt házastársának legközelebbi rokona vagy az

\footnotetext{
11 Indokolás 1946

12 Mtj. 192. \$

${ }^{13}$ Mtj. 196. \; 202. \$

$14 \mathrm{Mtj} .245 .8$

$15 \mathrm{Mtj}$. 247. S

${ }_{16} \mathrm{Mtj}$. 248. S

$17 \mathrm{Mtj} .259 . \mathrm{S}^{2}$

${ }^{18} \mathrm{Mtj}$. 246. $\mathrm{S}$

19 Mtj. 267. \$

${ }^{20} \mathrm{Mtj} .322 .5$
} 
örökhagyó közokiratban elismert házasságon kívüli gyermeke a törvényes örökös. ${ }^{21}$ Atyjának hagyatékában más örökös nemlétében az államkincstárt megelőzve a házasságon kívüli gyermek volt a törvényes örökös, ha atyja ôt közokiratban a magáénak elismerte. ${ }^{22}$ A házasságon kívül született gyermek és anyja közt sem volt hosszú időn át öröklési kapcsolat és az ilyen gyermek még a 20. század első éveiben is csak akkor örökölt az anyja után, ha annak házasságból származó gyermeke nem volt. Ezen a helyzeten a Curia 79. számú döntvénye változtatott azzal, hogy kimondta, hogy a végrendelet nélkül elhalt anya hagyatékára nézve a törvénytelen gyermeknek törvényes leszármazó esetében is van törvényes örökösödési joga.23 A bíróságok a döntvény indokolására támaszkodva több olyan határozatot hoztak, amelyben a házasságon kívül született gyermek öröklési jogát anyja rokonainak hagyatékára is elismerték, a Curia azonban 1907. április 25. napján tartott értekezletén megállapította, hogy a 79. számú döntvény a rokonok után való öröklésre nem vonatkozik. Az elhalt gyermek törvényes leszármazójának törvényes örökösödési jogát anyai nagyanyja hagyatékára a Curia 1913-ban ismerte el, ${ }^{24}$ 1915-ben pedig kimondta, hogy ha az anya, aki törvénytelen gyermeket hagyott hátra, előbb hal meg, mint az a rokona, aki után az anya örökölt volna, a törvénytelen gyermeket a képviseleti elv alapján az anyának említett rokona után törvényes örökösödési jog illeti meg és viszont. ${ }^{25}$

Ezen a ponton állt meg örökösödési vonatkozásban a házasságon kívül született gyermekekre vonatkozó jogunk fejlődése és ez a pont jelenti a családfejlődés megszakadását is. ${ }^{26}$

\section{A törvénytelen származás megszüntetése a házasságon kívül született gyermek jogállásáról szóló 1946. évi XXIX. törvénycikkben}

A házasságon kívül született gyermek jogállásáról szóló 1946. évi XXIX. törvénycikk indokolásának szóhasználata szerint a demokratikus Magyarország törvényhozásának egyik elsőrendû kötelessége volt, hogy a törvényes és a törvénytelen származás megkülönböztetését az emberi lehetőségek határain belül minél előbb megoldja, ${ }^{27}$ az emberi egyenlőség eszméjének szolgálatában a családi jogállás egyenlőségét is a származástól függetlenül az élet minden vonatkozásában minél teljesebben érvényesítse. Ennek megfelelően a törvénycikk 1. \-a így szólt: „A jelen törvény erejénél fogva a törvényes és törvénytelen sqármaz̧ás megkülönböztetése megszünik”.".28 A törvénytelen megjelölés ártatlan emberek meg nem érdemelt megbélyegzése volt; ezért a jogszabály ezt a megjelölést házasságon kívüli gyermekre változtatta. ${ }^{29}$ Ugyanakkor azonban, amikor a magyar jogrendszer a törvénytelen elnevezéssel szakított, változatlanul fenntartotta a házasságon kívüli gyermek fogalmát és az ezzel összefüggő törvényesítés jogintézményét. ${ }^{30}$ A családi jogállás egyenlősége nem jelentette a

\footnotetext{
${ }^{21}$ Mtj. 1781. S

$22 \mathrm{Mtj} .1784 . \$$

${ }^{23}$ A Curia 79. számú döntvénye (1906. november 9.) és Indokolás 1946

${ }^{24}$ A Curia 2553/1913. sz. határozata és Indokolás 1946

25 A Curia 2488/1914. számú határozata (1915. január hó 13.) és Indokolás 1946

26 Indokolás 1946

27 Indokolás 1946

28 1946. évi XXIX. tc. 1.S

${ }^{29}$ A magánjogi törvénykönyvünk 1928. évi javaslata is a házasságon kívüli gyermek megjelölést használta; Indokolás 1946

30 Indokolás 1946
} 
házasságból és a házasságon kívül született gyermekekre vonatkozó összes jogszabály alaki és tartalmi azonosságát, hanem lehetőség szerint hozta ugyanabba a helyzetbe őket, mint amelyben a házasságból született gyermekek voltak. ${ }^{31}$

A törvénycikk első alapelve tehát az volt, hogy a gyermeki származás megkülönböztetése megszúnjön, a törvényesnek tekintett gyermeket házasságból születettnek, a többit pedig házasságon kívül születettnek nevezze. E megkülönböztetés logikai szempontból nem volt kifogásolható, tartalmilag a valóságnak megfelelt, értékelést nem fejezett ki. ${ }^{32}$

A jogszabály második alapelve az volt, hogy a házasságból és a házasságon kívül született gyermek jogállása egyenlő, a házasságon kívül született gyermek nemcsak az anyjával és annak rokonaival, hanem az atyjával és annak rokonaival is rokoni, tehát öröklési kapcsolatban is állt, atyja családi nevét viselte. ${ }^{33} \mathrm{Az}$ öröklési kapcsolat a házasságon kívül született gyermek rokonai közt természetesen kölcsönös, tehát nemcsak a házasságon kívül született gyermek örökölt atyja és annak rokonai, hanem azok is örököltek a házasságból született gyermek után. ${ }^{34}$ A törvényes származás vélelme kiterjedt a vélt házasságból származó gyermekre, valamint minden érvénytelen házasságból származó gyermekre is. ${ }^{35}$

A jogszabály 3. \$-a kimondta, hogy házasságon kívül születettnek azt a gyermeket kell tekinteni, akinek anyja a gyermek születésnapjától visszafelé számított háromszáz nap alatt beleszámítva a születés napját is - házassági kötelékben nem állott, vagy akit jogerős bírói ítélet házasságon kívül születettnek nyilvánított. ${ }^{36}$ A házasságon kívül született gyermek atyjának a jogszabály azt az atyát nevezte, aki a gyermeket teljes hatályú elismerő nyilatkozattal a magáénak ismerte el, vagy akit a bíróság jogerős ítélettel a gyermek atyjának nyilvánított. ${ }^{37}$ A házasságon kívül született gyermek és atyja közt erkölcsi vonatkozásban is ugyanaz a kapcsolat létesült, amely a házasságból született gyermek és atyja között fennállt. E kapcsolat folytán a házasságból született gyermek is köteles volt atyja iránt tisztelettel viseltetni, atyja pedig erkölcsileg is felelős volt gyermeke sorsáért. Ezek az erkölcsi kötelmek jogilag nem voltak kikényszeríthetőek (a törvénycikk külön nem rendelkezett róluk), de például a szülői hatalommal kapcsolatban jogi következménye volt annak, ha az atya magatartásában gyermeke iránt nem mutatkozott meg az a felelősségérzet és gondoskodás, amely jó atyától a természet rendje és az erkölcs szabályai szerint elvárható lett volna. ${ }^{38}$

A fentiekre figyelemmel a házasságon kívül született gyermekeknek így két csoportja lett: az egyik csoportba azok tartoztak, akik az említett vélelem alapján házasságból születetteknek nem tekinthetők, mert nem házasság alatt, illetve a házasság megszűnésétôl számított háromszáz napon belül születtek, a másik csoportba pedig azok, akik az említett vélelem alapján ugyan házasságból

\footnotetext{
31 Indokolás 1946

32 Indokolás 1946

33 Indokolás 1946

34 Indokolás 1946

35 Indokolás 1946

36 1946. évi XXIX. tc. 3.S

37 1946. évi XXIX. tc. 9.S

38 1946. évi XXIX. tc. 25.』 (2) és Indokolás 1946
} 
születettek, a bíróság azonban az erre irányuló perben hozott jogerős ítélettel házasságon kívül születetteknek nyilvánította őket. ${ }^{39}$

A házasságon kívül született gyermek egyik legfájóbb sérelme az volt, hogy házasságon kívül születését az anyakönyv és az anyakönyvi kivonat alapján azonnal meg lehetett állapítani, mert azokba atyja bejegyezve nem volt. Ez a helyzet megváltozott, mivel a házasságon kívül született gyermek atyja a teljes hatályú atyai elismerés, a jogerôs bírói ítélet, vagy az utólagos házasságkötés alapján a születési anyakönyvbe éppúgy bejegyezhetővé vált, mint a házasságból született gyermek atyja. ${ }^{40} \mathrm{Az}$ állami anyakönyvbe a gyermek házasságon kívüli születésének tényét vagy erre utaló adatot bejegyezni nem volt szabad. Ha a házasságon kívül született gyermek harmadik életévének betöltéséig atyja teljes hatályú elismerő nyilatkozata, az atyaságot megállapító bírói ítélet vagy az anya utólagos házasságkötése alapján nem volt bejegyezhető, hivatalból kellett intézkedni az iránt, hogy a születési anyakönyvbe a gyermek atyjaként képzelt személy jegyeztessék be. Az intézkedésre a gyámhatóság volt hivatott, melyhez a jogszabály iránymutatást is adott: a gyámhatóság a képzelt atya családi nevéül az anya legközelebbi ismert anyai ági férfi elődének családi nevét, vallásául pedig az anya vallását határozta meg. ${ }^{41}$ Így tehát a házasságon kívül született gyermekeknek legkésőbb hároméves korukban az anya családi nevétől eltérő családi neve lehetett, ily módon megszűntek azok a sérelmek, amelyek a gyermeket családi neve miatt érték. ${ }^{42}$

Az, hogy a jogszabály néhol a házasságban és a házasságon kívüli gyermek között eltérő rendelkezéseket határozott meg, nem jelentette a jogegyenlőség megsértését, hanem kényszerű következménye volt annak, hogy az eltérő életviszonyokra tekintettel egyes vonatkozásokban eltérő jogi utakon lehessen megközelíteni az anyagi jogegyenlőséget. Ilyen eltérő rendelkezést tartalmazott például a házasságon kívül született gyermek elhelyezése, a szülői hatalom, a tartás tekintetében. Ez a diszkrepancia nem volt jelentős, a házasságon kívül született gyermek érdekeit szolgálta és nem jelentett a házasságból származó gyermekkel szemben a házasságon kívüli gyermek javára előnyösebb helyzetet.43

Ha a házasságon kívül született gyermek atyja és anyja nem élt együtt, megegyezés hiányában a gyámhatóság határozott, hogy a gyermeknek melyikük viselje gondját. Ilyen esetben a leánygyermeket és a hétévesnél fiatalabb fiút rendszerint az anya, a hétévesnél idősebb fiút általában az atya gondviselésére bízták. ${ }^{44}$ A házasságon kívül született gyermek felett az atya csak akkor gyakorolta a szülői hatalmat, ha nagykorú volt és a gyermeket rábízták, vagy a szülői hatalom gyakorlását a gyámhatóság fontos okból ráruházta. Ebben az esetben a szülői hatalom gyakorlását akkor is meg lehet szüntetni, ha az atya magatartásában gyermeke iránt nem nyilatkozott meg az a felelősségérzet és gondoskodás, amely a jó atyától a természet rendje és az erkölcs szabályai szerint elvárható volt. Ezeken az eseteken felül a házasságon kívül született gyermek felett a nagykorú anya gyakorolta a szülői hatalmat akkor is, ha annak gyakorlása az atyát az előbbiekben említettek szerint nem illette meg, vagy ha a gyermeknek atyja nem volt. ${ }^{45}$ Előfordult, hogy a házasságból származott

\footnotetext{
${ }^{39}$ Indokolás 1946

40 Indokolás 1946

41 1946. évi XXIX. tc. 22.S

42 Indokolás 1946

${ }^{43}$ Indokolás 1946

44 1946. évi XXIX. tc. 24.

45 1946. évi XXIX. tc. 25.§
} 
gyermek felett az anyja gyakorolta a szülői hatalmat. Ez a jog a házasságon kívül született gyermek anyját is megillette, feltéve, hogy az anya nagykorú volt.

A házasságon kívül született gyermek tartása vonatkozásában azok a jogszabályok voltak irányadók, amelyek a házasságból származott gyermek tartását a házasság fennállása alatt rendezték. ${ }^{46}$

A törvényes és törvénytelen származás megkülönböztetésének megszüntetésével attól is tartani lehetett, hogy a férfi számára sokkal kevesebb kötelezettséggel jár, ha házasságon kívül lép nővel nemi viszonyba és amikor akarja, megszakítja azt, ennek következményeként mind kevesebben kötnek majd házasságot, és idővel a házasság felesleges jogintézménnyé válik. Ez az elképzelés megcáfolható volt azzal, hogy az a férfi, aki azért nem köt házasságot, mert a házasságon kívül született gyermeke jogállása egyenlő lenne a házasságból született gyermeke jogállásával, a megváltozott jogszabály miatt sem volt kénytelen házasságot kötni, mivel a házasságon kívül született gyermekét - amennyiben szerette volna - ugyanabba a helyzetbe hozhatta (törvényesíthette, örökbe fogadhatta, vagyonát neki ajándékozhatta, vele öröklési szerződést köthetett, vagyonát végrendelet útján reá ruházhatta). ${ }^{47}$ A házasságból és a házasságon kívül született gyermek jogállásának egyenlőségétől sokan az atya családi békéjét féltették és nem helyeselték, hogy a jogszabály a házasságon kívül született gyermeket belekényszeríti atyja családjába. A törvényhozók erre is figyelemmel voltak, mivel a jogszabály ugyan a házasságon kívül született gyermeket az atya családja egyenlő jogú tagjává tette, azonban tartózkodott attól, hogy az atya gondviselésére bízza, ha az atya házastársa (aki nem a gyermek anyja) ehhez nem járult hozzá, vagy ez a házasságból származott gyermek jogos érdekével ellentétes lett volna. ${ }^{48} \mathrm{~A}$ nő jogállása nem függött a házasságon kívül született gyermek jogállásától, éppúgy érdeke volt a férfihoz való kapcsolatának a házasságkötés útján való rendezése, mint azokban az időkben, amikor a házasságon kívül született gyermek jogállása a legkedvezőtlenebb volt. A házasságon kívüli nemzés megszüntetésével minden súlyos társadalmi és hátrányos gazdasági következmény is megszűnni látszott, amelyet a nő és a házasságon kívüli gyermeke viselt, ugyanis a házasságon kívül született gyermek nemzője éppúgy atyja lett gyermekének, mintha a gyermek anyjával házasságra lépett volna, a gyermek éppúgy a nevét viselte, ugyanolyan jogai voltak vele szemben, éppúgy örökölt utána. Éppen ezért a reformtól inkább a házasságok számának emelkedését várták. ${ }^{49} \mathrm{~A}$ statisztikai adatok szerint a házasságon kívül történt születések száma éppen ettől az időtől kezdve rohamosan csökkent. Amíg ugyanis 1900-ban és 1901-ben egy év alatt 1.000 nem férjezett 15-49 éves nőre 43 házasságon kívül történt születés esett, 1938-ban csak 15, ugyanezen idő alatt 1.000 lélekre eső nyers arányszám 3,7-ről 1,7-re, az összes születésekhez viszonyított arányszám 9,2-rôl 8,4-re csökkent. ${ }^{50}$

Herger Csabáné jogtörténész a Magyar Nemzeti Levéltár Baranya Megyei Levéltárában, a Pécsi Királyi Törvényszék előtt 1895 - 1918 között folyamatba vett köteléki perekben végzett kutatása során, a felbontott házasságok termékenységének vizsgálatakor megállapította, hogy az

\footnotetext{
46 1946. évi XXIX. tc. 26.

47 Indokolás 1946

48 1946. évi XXIX. tc. 24. \(2)

${ }^{49}$ Indokolás 1946

50 Indokolás 1946
} 
országos adatok szerint az 1902-ben felbontott házasságok 44,03 \%-ában nem született gyermek, az 1909-ben felbontott házasságok abszolút többsége, vagyis 55,4 \% gyermektelen volt. A pécsi királyi törvényszék előtt a gyermektelen házasságok aránya kevés kivételtől eltekintve 40-72\% között mozgott a házassági jogról szóló 1894. évi XXXI. tc. (a továbbiakban: Ht.) hatálybelépését követő 24 évben, azaz 1895 - 1918 között. ${ }^{51}$

Ha a házasságból nem született gyermek, ennek közvetett hatása abban nyilvánult meg, hogy a feleket nem kötötte a gyermek felnevelésének kötelezettsége és a kapcsolatból könnyebben ki lehetett lépni. ${ }^{52}$ A közös kiskorú gyermek léte a házassági kötelék fenntartására pozitív hatást elvileg akkor gyakorolhatott, ha a házasfeleknek mástól nem született gyermekük. 1895 - 1918 közötti években átlagosan 2,5 \%-ban a házasságból és egy másik kapcsolatból is született utód. Ezekben az esetekben általában a házastársak hosszú idő óta tartó különélésérôl illetve ágyasságról volt szó. 1896-ban (a Ht. hatálybalépését követő 1-1,5 évben) fordult elő legmagasabb arányban (18,2\%) a házassági köteléki perek között olyan eset, amikor a házassági életközösség felbontását a különélő felek az ágyasság legalizálása, legtöbbször az abból született gyermekek törvényesítése, illetve a volt feleség ágyassága esetén a férj részéről a törvénytelen származás megállapítása érdekében kezdeményezték a polgári jogrend adta lehetőséggel élve. ${ }^{53}$

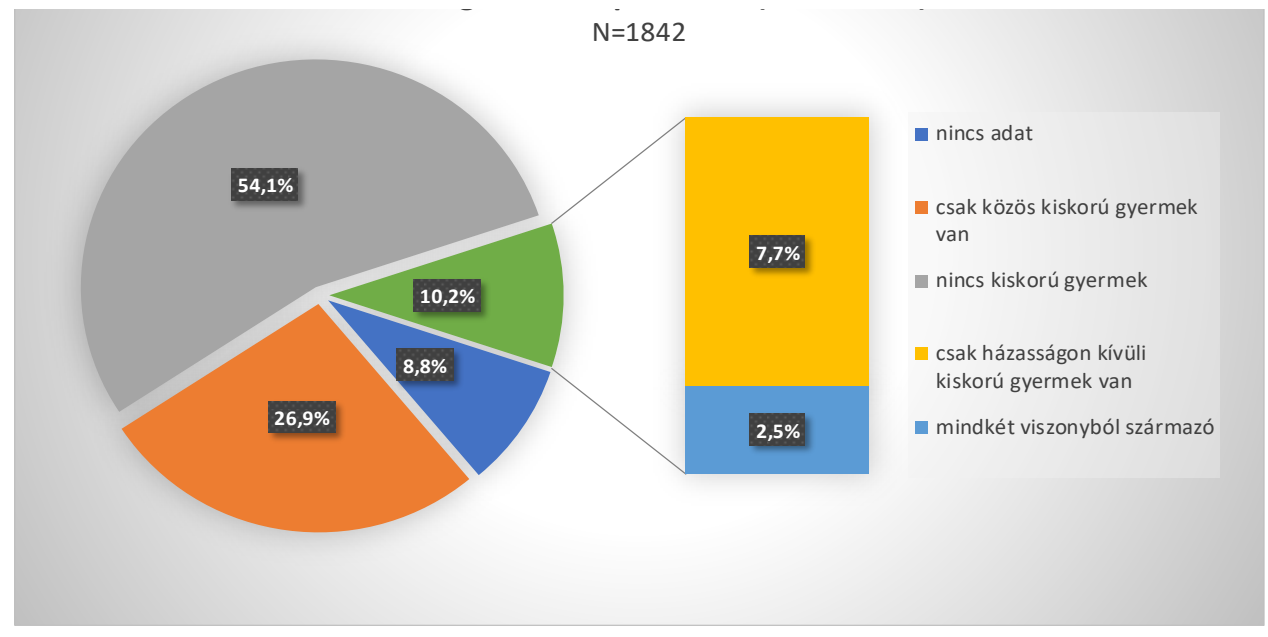

1. ábra: A közös kiskorú gyermekek és a házasságon kívül született kiskorú gyermekek aránya a Pécsi Királyi Törvényszék előtt folyamatba tett házassági köteléki perekben, 1895-1918 (Forrás: HerGER, A nővételtől az állami anyakönyvvezetőig 209.)

A törvénycikk tehát nem azoknak a házasságon kívül született gyermekeknek a sorsát javította, akikkel atyjuk ilyen módon törődött, hanem azokét, akiknek atyját kötelessége teljesítésére kényszeríteni kellett. Kétségtelen, hogy voltak olyan házasságon kívül született gyermekek is, akiknek atyját a bíróság nem tudta megállapítani. Ez köszönhető volt annak is, hogy a bíróság

\footnotetext{
${ }^{51}$ Herger, A nővételtôl az állami anyakönyvvezetőig 207.

52 HerGER, A nóvételtôl az állami anyakönyvvezetóig 208.

${ }^{53}$ HerGER, A nővételtől az állami anyakönyvvezetőig 209.
} 
belátásától függött, megállapítja-e a fogantatási idő alatt történt nemi érintkezés tényét valamelyik fél esküvel megerősített vallomása alapján vagy sem. ${ }^{54}$

\section{Az örökbefogadás szabályozása Magyarország Magánjogi Törvénykönyvének javaslatában}

Hazánkban két jogterületet különböztettek meg: az egyik Magyarországnak a Királyhágón innen való része, ahol a tradicionális magyar magánjoghoz a neoabszolutizmus korának erôszakos jogexportja után az Országbírói Értekezlet túlnyomó részben visszatért (1861), a másik a Királyhágón túl fekvő Erdély volt, a polgárosított és az anyaországhoz csatolt határôrvidék valamint Fiume, ahol az Osztrák Polgári Törvénykönyv (a továbbiakban: Optk.) 1861 után is hatályban maradt. Ehhez képest az örökbefogadás intézménye is kétféleképpen volt szabályozva; a Korona mellékországaiban az Optk. volt az irányadó, Magyarországon pedig az 1877. évi XX. tc.

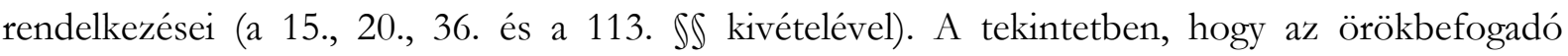
szerződés kormányhatósági megerősítésénél melyik nyert alkalmazást, az örökbefogadó lakóhelye volt az irányadó, ha az örökbefogadó és az örökbefogadott magyarországi községi illetőségú magyar állampolgár volt, valamint ha az örökbefogadó Magyarország területén lakott. Ha az örökbefogadó külföldön vagy Horvát-Szlavónország területén lakott, akkor az a jog volt alkalmazandó, mely illetőségű községe területén érvényben volt. 55

Pesthy Pál igazságügyi miniszter ${ }^{56}$ 1928. március elsején nyújtotta be a képviselőházba az 1928. évi magánjogi törvényjavaslatot és a benyújtás alkalmával hangsúlyozta, hogy - mint igazságügyi miniszter - súlyt helyez a javaslat mielőbbi letárgyalására. Az Mtj. személyi és családjogi intézményei közül a legerôsebb hatást az örökbefogadás váltotta ki ${ }^{57}$ Hogy az idő mennyire sürgette az örökbefogadás mielőbbi végleges szabályozását, az kitűnt abból, hogy a bajba jutott, háború következtében szétszakadt családok a rádió igénybevételével óhajtották elhelyezni, illetve örökbe adni gyermekeiket módos családoknak, mert a gyermekeik éheztek, őket eltartani nem tudták. ${ }^{58}$

A házasságon kívül született gyermek törvényesítésének egyik eszközeként is szabályozta az Mtj. az örökbefogadás intézményét, kimondta, hogy a házasságon kívüli gyermek örökbefogadása nem gátolja az örökbefogadott törvényesítését. $\mathrm{Ha}$ az örökbefogadottat örökbefogadója törvényesítette, az örökbefogadás a törvényesítéssel megszűnt, az örökbefogadásból rokonság keletkezett azok között is, akikre a törvényesítés és az örökbefogadás kihatott. ${ }^{99} \mathrm{~A}$ törvényesített, saját gyermek örökbefogadását a törvény expressis verbis kizárta. ${ }^{60} \mathrm{~A}$ Curia egyik döntésében kimondta, hogy az örökbefogadó elhunyt apjának iparát az örökbefogadott

\footnotetext{
${ }^{54}$ Indokolás 1946

55 GAÁr, Az örökbefogadásról 3-4.

56 Koronczói Pesthy Pál (Uzdborjád, 1873. július 9. - Sárszentlőrinc, 1952. május 7.) magyar jogász, Curiai bíró, országgyúlési képviselő (Egységes Párt), igazságügy-miniszter (1924 - 1929).

${ }^{57}$ GÁL - NYÁRÁDY, Az örökbefogadás 3.

58 GÁL - NYÁRÁDY, Az örökbefogadás 101.; A Magyar Nemzeti Levéltár Baranya Megyei Levéltárában végzett kutatásaim alapján magam is megállapítottam, hogy 1872-1923 között rengeteg gyermek került állami gondozásba, mivel édesapjuk a háborúból nem tért vissza, édesanyjuk pedig nem volt képes eltartani őket.

${ }^{59}$ Mtj. 174. \és 222. §; az Optk. szerint a törvénytelen gyermeket természetes apja nem fogadhatta örökbe ld. bővebben: GÁL - NYÁRÁDY, Az örökbefogadás 29.

${ }^{60}$ MESZLÉnY, Magyar Magánjog I. 711.
} 
kiskorú gyermek nem folytathatta, mert annak nem unokája, mivel az örökbefogadott gyermek és az örökbefogadó szülei között rokonság nem létesült. ${ }^{61}$

Az Mtj. az aktív örökbefogadási képességet a nagykorú és ivadék ${ }^{62}$ nélküli személyeknek tette lehetôvé, az életkor tekintetében egy követelményt támasztott: az örökbefogadott legalább tizenhat évvel legyen fiatalabb a leendő örökbefogadónál.63 Az igazságügyi miniszter különös méltánylást érdemlő esetben megerősíthette a szerződést akkor is, ha az örökbefogadónak vérszerinti ivadéka volt, vagy ha a korkülönbség kelléke hiányzott, de ebben az esetben is az örökbefogadottnak legalább tizenkét évvel fiatalabbnak kellett lennie az örökbefogadónál.64 A tizenkét évi minimális korkülönbség megállapítását az indokolta, hogy ez az a korminimum, amely feltétlenül szükséges az érvényes házasság megkötéséhez, ennél fogva ahhoz, hogy valakinek törvényes leszármazói legyenek. ${ }^{65}$ Gál Dezsố és Nyárády László budapesti ügyvédek álláspontja szerint nagyszerű gyakorlata volt az örökbefogadási rendszernek, hogy az örökbefogadó-képesség nem volt bizonyos magasabb korhatárhoz kötve, mint például a német ptkv. (1744. \) szerint az örökbefogadónak legalább 50 évesnek, a spanyol ptk. (173. 』) szerint 45 évesnek, a svájci ptk. (264. \) szerint 40 évesnek kellett lennie. ${ }^{66}$

A törvény nem határozott meg felső határt az egy háztartásban élő örökbefogadott gyermekek számát illetően. ${ }^{67}$ Házastársakat kivéve többen ugyanazt a személyt nem fogadhatták örökbe. (Az örökbefogadó halála után az igazságügyi miniszter különös méltánylást érdemlő esetben kivételt engedhetett.) Senki sem fogadhatta örökbe saját házastársát vagy házastársának elődjét. 68

Az örökbefogadáshoz való hozzájárulás tekintetében a kódex különbséget tett törvényes és házasságon kívüli gyermek között. Kiskorú törvényes gyermeket csak szüleinek, kiskorú házasságon kívüli gyermeket csak anyjának beleegyezésével lehetett örökbe fogadni. Házastárs csak házastársának beleegyezésével fogadhatott örökbe és volt örökbe fogadható, kivéve, ha a házastársak ágytól és asztaltól el voltak választva. ${ }^{69}$

A hozzájárulást csak a házastárs és a szülő adhatta meg és azt közokiratban kellett kijelenteni vagy közhatóság előtt jegyzőkönyvbe mondani, amely joghatását tekintve visszavonhatatlan volt. A házastárs, a szülő beleegyezése alól a törvényjavaslat kivételt engedett távollét, cselekvőképtelenség esetén, vagy ha egyéb ok miatt tartósan gátolva volt a nyilatkozat megtételében. A felek

\footnotetext{
${ }^{61}$ C.III.482/1932.

${ }^{62}$ Ivadék alatt az Mtj. 175. \a lemenő rokont érti.

${ }^{63}$ A törvényes leszármazók hiánya csak az ország azon részeiben képezte az örökbefogadás feltételét, ahol az osztrák polgári törvénykönyv ideiglenes hatályban volt, ellenben az ország többi részében az a körülmény, hogy az örökbefogadónak törvényes leszármazói vannak, az örökbefogadást nem akadályozta. Lásd bővebben GAÁR, Az örökbefogadásról 9.

${ }^{64} \mathrm{Mtj} .207 . \S$

${ }^{65}$ GÁL - NYÁRÁDY, Az örökbefogadás 29. és 1894. évi XXXI. tc. 7. \

${ }^{66}$ GÁL - NYÁRÁDY, Az örökbefogadás 25-26.

${ }^{67} \mathrm{Mtj} .207 . \mathrm{S}$

${ }^{68}$ Előd alatt a felmenő rokont értették. Mtj. 175. \és 208. \

${ }^{69}$ Mtj. 209. §; az ágytól és asztaltól való különélés hat hónapnál rövidebb és egy évnél hosszabb időtartamú nem lehetett, amely alatt a házastársak nem voltak kötelesek együtt élni. A különélés ideje alatt a házassági életközösséget bármikor visszaállíthatták. Az ágytól és asztaltól való különélés elrendelése esetében a bíró intézkedett a közös kiskorú gyermek elhelyezése, valamint a nőnek tartása és a szükséges tárgyak kiadása iránt. Lásd bővebben 1894. évi XXXI. tc. 99-102. S
} 
örökbefogadás iránti szándékát - valamint, ha az örökbefogadandó gyermek a 14. életévét betöltötte, az ô véleményét - az eljáró árvaszék vagy a lakóhelyükhöz legközelebb eső szolgabíróság vette jegyzőkönyvbe.

A passzív örökbefogadási képesség, azaz, hogy kit lehetett örökbe fogadni, kiterjedt a nagykorú személyre is, aki maga vagy meghatalmazott útján köthette meg a szerződést. ${ }^{70}$

Az örökbefogadás 1953-ig szerződéses jogügylet volt, melyet közokiratba kellett foglalni. Az örökbefogadást sem feltételhez, sem időhöz nem lehetett kötni. ${ }^{71}$ A kir. Curia mint legfőbb ítélőszék 1874. július 28. napján 6307. sz. és az 1879. július 21. napján 6581. sz. határozataiban kimondta ugyan, hogy az örökbefogadó szerződés érvényéhez kormányszéki jóváhagyás nem igényeltetik, azonban a magyar törvényeknek 1861-ben történt visszaállítása óta a kormányhatóságok által követett gyakorlat megkövetelte az örökbefogadói szerződések kormányhatósági megerősítés céljából való felterjesztését.

1867 óta a magyar királyi igazságügyi miniszter erősítette meg a szerződéseket, mely nem jelentett érvényességi feltételt, csupán konstitutív jellege tanúsította, hogy a szerződés a felek akaratából köttetett, az alaki és anyagi jogszabályoknak megfelelő liquid ügylet, mely arra is szolgált, hogy harmadik személyekkel szemben tanúsítást nyerjen az örökbefogadás tényével és a névváltozás anyakönyvi bejegyzésével. A megerősítés közrendészeti szempontból volt jelentős, mert a jogügylet azért lett megerősítve, mert joghatályos örökbefogadási ügylet keletkezett a felek között. A megerősítés megtagadása ellen az érintettek számára egy jogorvoslati lehetôség állt nyitva: a bírói út. ${ }^{72} \mathrm{Az}$ örökbefogadó szerződés az igazságügyi miniszteri megerősítéssel lépett hatályba mind kiskorú, mind nagykorú örökbefogadott esetében, melyet az igazságügyi miniszter rendeleti formában adott ki. A rendelet két fő részre tagolódott: elsőként a kormányhatósági megerősítést tartalmazta, majd a közvetítő hatóságokhoz szóló utasítást - kiskorúak esetében az árvaszékhez, nagykorúaknál pedig a törvényszékhez -, hogy lássák el a szerződés példányait megerősítő záradékkal, intézkedjenek az örökbefogadás ténye, a névváltozás vagy annak a ténynek az anyakönyvbe való bejegyzéséről, hogy az örökbefogadott neve nem változott, a feleket pedig az iratok egyidejű megküldésével értesítsék. ${ }^{73}$

Az igazságügyi miniszteri megerősítést a bírói megerősítéssel szemben több szempont indokolta, például az is, hogy a bírói úttal a jogegység nem lett volna megóvható, hiszen mellőzhetetlen lett volna a jogorvoslat, valamint az ügyek elhúzódása is feltételezhető volt. Az igazságügyi minisztérium házassági, törvényesítési és örökbefogadási ügyosztálya minden állam örökbefogadási jogrendszerét ismerte, kiváló szakemberekkel dolgozott, akik gyorsan végezték munkájukat. ${ }^{74}$

\footnotetext{
${ }^{70}$ GÁL- NYÁRÁDY, Az örökbefogadás 28. és 122.

${ }^{71}$ Mtj. 212. \$

72 MESZLÉNY, Magyar Magánjog I. 703.

${ }^{73}$ MESZLÉNY, Magyar Magánjog I. 701-702.

${ }^{74}$ GÁL - NYÁRÁDY, Az örökbefogadás 112-113.
} 


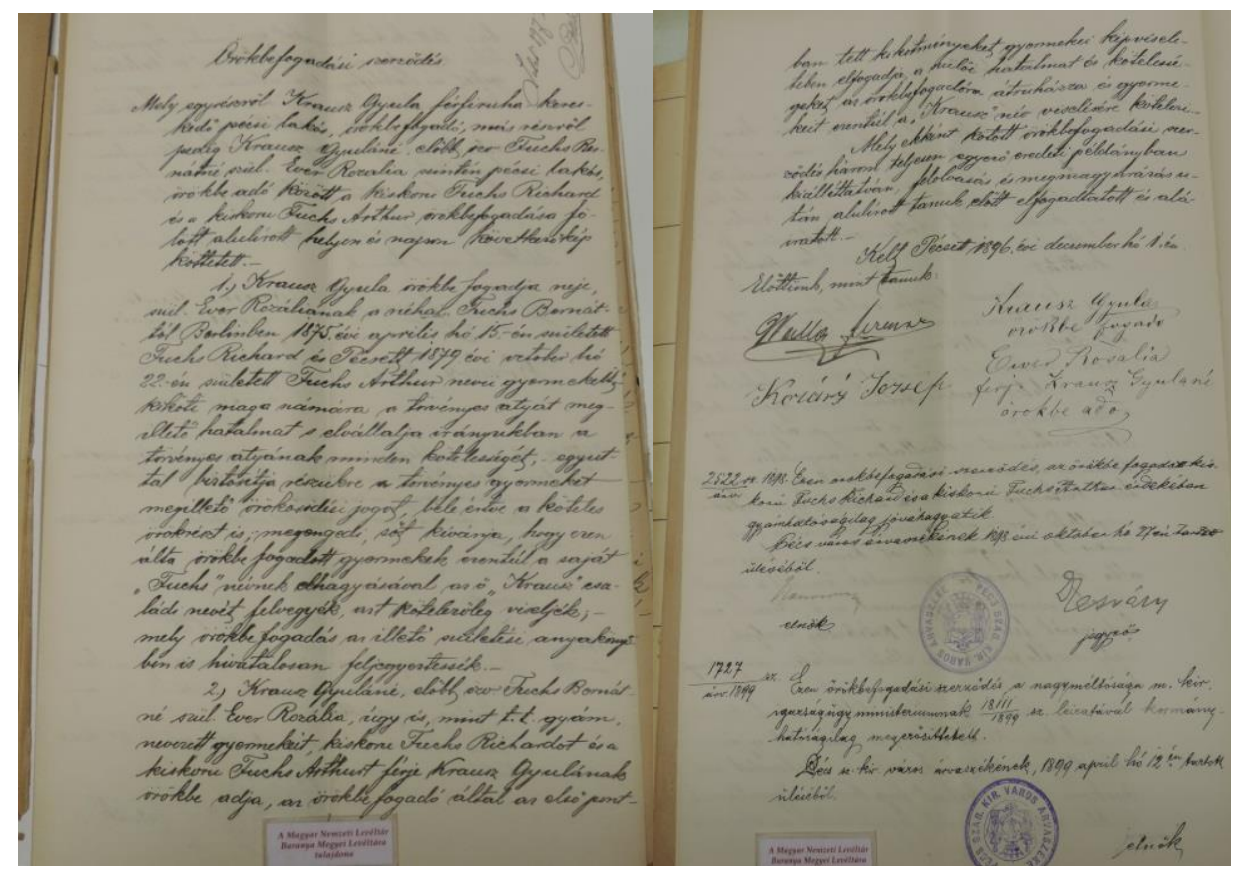

2. ábra: 1986. évben kelt örökbefogadási szerződés Fuchs Arthur és Fuchs Richard kiskorú gyermekek ügyében, MNL BML IV. 1904.b II.-275-1900 (Forrás: a szerző gyūjtése)

Az örökbefogadó szerződést az örökbefogadónak az örökbefogadandóval kellett megkötnie. A kiskorú törvényes képviselője elsősorban az atyai hatalmat gyakorló atyja volt; ha az atya nem élt vagy az örökbefogadott törvénytelen születésű volt, akkor az anya; ha az atyai hatalom gyakorlata felfüggesztetett vagy egyik szülő sem élt, akkor az árvaszékileg kirendelt gyám következett a sorban, aki megköthette az örökbefogadó szerződést. ${ }^{75}$ A szerződést törvénytelen származású kiskorú gyermek esetében az anyával mint természetes és törvényes gyámjával kellett megkötni. ${ }^{76} \mathrm{Ha}$ az örökbefogadandó a tizenkettedik életévét még nem töltötte be, a gyámhatóság jóváhagyásával törvényes képviselője köthette meg a szerződést. ${ }^{77} \mathrm{E}$ szerződést három eredeti példányban közokiratba kellett foglalni, kivéve, ha királyi közjegyző előtt köttetett, mert akkor három hiteles kiadványa készült. ${ }^{78}$ Kiskorú örökbefogadása esetén a gyámhatóság a jóváhagyás előtt rövid úton megkérdezte az igazságügyi minisztériumot, hogy vajon a szerződés megerősítésére számítani lehet-e, mert csak akkor hagyták jóvá, ha igenlő választ kaptak. A minisztérium rövid úton is, telefonon keresztül is adott a hatóságoknak irányító választ.79

Az örökbefogadó szerződésben az örökbeadó atyának egyértelműen fenn kellett tartania az atyai hatalmat, az anyának a törvényes gyámságot, mert különben az az örökbefogadó atyára/anyára szállt át. Mindez az igazságügyi minisztérium gyakorlatában kristályosodott ki, melynek során arra

\footnotetext{
${ }^{75}$ MESZLÉNY, Magyar Magánjog I. 698.

${ }^{76}$ GÁL - NYÁRÁDY, Az örökbefogadás 72. (C.III.2184/1927.)

${ }^{77} \mathrm{Mtj} .211 . \mathrm{S}$

${ }^{78}$ MESZLÉNY, Magyar Magánjog I. 699.

${ }^{79}$ GÁL - NYÁRÁDY, Az örökbefogadás 118-119.
} 
is figyelemmel kellett lenni, hogy az atyai hatalmat csak az örökbeadó atya ruházza át az örökbefogadó atyára, ellenben az örökbefogadó anyára még az örökbeadó atya is csak a törvényes gyámságot ruházhatta át. ${ }^{80} \mathrm{Az}$ igazságügyi miniszter a megerősítést csak akkor tagadhatta meg, ha az örökbefogadásnak valamely törvényes kelléke hiányzott, vagy ha a feleknek a körülményekből nyilvánvaló akarata a valóságban nem családjogi viszony alapítására irányult. ${ }^{81}$ A szerződésbe nem volt felvehető olyan kikötés, mely szerint az örökbefogadó szülők az örökbefogadandó gyermekkel szemben mindazon jogokat igénylik, amelyek a szülői és gyermeki viszonynál fogva a személyi, vagyoni kérdésekből folynak. Ugyancsak nem volt kiköthető az örökbefogadott után az örökbefogadó javára való örökösödési jog, ahogy az sem, hogy az örökbefogadó szülőt az örökbefogadott gyermek után mindazon jogok megilletik, melyek a szülőt a törvényes gyermekei után illetik. Ha ezek mégis felvételre kerültek, akkor az igazságügyi minisztérium megtagadta az örökbefogadó szerződés kormányhatósági megerősítését. ${ }^{82}$ Amennyiben helytelenül volt megszövegezve a szerződés, akkor azt az igazságügyi minisztérium pótlás végett visszaadta. ${ }^{83} \mathrm{Az}$ örökbefogadás lényegét nem érintő szabályozásokat, kikötéseket azért nem foglalhatták bele a szerződésbe, mert ezek a kötelem tisztaságát, a vállalt kötelezettségek jogi elbírálását tették nehézkessé, mindezek mellett az igazságügyi miniszter más irányú szerződéses rendelkezéseket meg sem erősíthetett. ${ }^{84} \mathrm{Ha}$ egyidejűleg kiskorú és nagykorú gyermeket fogadtak örökbe, akkor arról külön szerződésben kellett rendelkezni. ${ }^{85} \mathrm{Az}$ örökbefogadó szerződés $50 \mathrm{kr}$. illetékbélyeg alá esett. ${ }^{86}$

Az örökbefogadott az örökbefogadó nemességét királyi jóváhagyással ellátott örökbefogadás által szerezte meg. Az örökbefogadáshoz járuló királyi jóváhagyás (consensus regius) a magyar nemesség adományozásának egyik módja volt, mely által a nem nemes a nemesi család tagjává és ezáltal magyar nemessé vált, ez a jóváhagyás az örökbefogadó szerződés megerősítéséül isszolgált. Először az igazságügyi minisztérium vizsgálta meg a szerződést, hogy az alakilag megfelel-e a törvényes kellékeknek és fel van-e szerelve megfelelő okirattal, majd a belügyminisztérium nyilatkozott a magyar nemesség átruházása tekintetében, különösen arról, hogy az örökbeadó magyar nemessége bizonyított-e. Magyar nemesség örökbefogadás útján csak magyar állampolgárra volt átruházható, fiúra vagy fiúval együtt leányra, azonban ha egyedül leány örökbefogadására került sor, akkor fiúsítás útján volt arra lehetőség, csak akkor, ha az örökbefogadó nemes férfi magszakadásához közel állt. Az örökbefogadó anya az örökbefogadott gyermekre nem terjeszthette ki nemességét. ${ }^{87} \mathrm{Az} 1920$. évi I. tc. ezt a fenntartott királyi jogkört senkire át nem ruházta, így csak nemesség nélküli magánjogi szerződést lehetett kötni, azonban a közjegyzői okiratban megállapodhattak a felek, hogy a nemességet utóbb fogják kérni királyi jóváhagyástól feltételezetten és az örökbefogadó erre az örökbefogadottat felhatalmazza arra az esetre is, ha akkora már nem volna életben. 88

\footnotetext{
${ }^{80}$ GAÁR, Az örökbefogadásról 18.

${ }^{81}$ Mtj. 213. S

${ }^{82}$ GAÁR, Az örökbefogadásról 10-11.

83 GAÁR, Az Örökbefogadásról 19.

${ }^{84}$ GÁL - NYÁRÁdY, Az örökbefogadás 33.

85 GAÁR, Az örökbefogadásról 24.

${ }^{86}$ GAÁR, Az örökbefogadásról 24.

${ }^{87}$ GAÁR, Az örökbefogadásról 29-31.

${ }^{8}$ GÁL - NYÁRÁDY, Az örökbefogadás 35.
} 
Az örökbefogadással az örökbefogadott az örökbefogadó törvényes gyermekének jogállásába lépett. Akit házastársak fogadtak örökbe, azt a házastársak közös törvényes gyermekének jogállása illette meg (közösgyermekké-fogadás). Közösgyermekké-fogadás volt az is, ha az egyik házastárs a másik házastárs gyermekét fogadta örökbe, kivéve, ha a feleség fogadta örökbe férjének házasságon kívüli gyermekét. ${ }^{89}$

Az örökbefogadó szerződéssel az örökbefogadó, közösgyermekké-fogadás esetében a férj saját családi nevét átruházhatta az örökbefogadottra. Az igazságügyi miniszter azonban a szerződés megerôsítését megtagadhatta, ha a névátruházás a közrend érdekével ellenkezett. Az örökbefogadó szerződésben a felek megállapodhattak arra nézve is, hogy az örökbefogadott az átruházott családi nevet saját családi nevéhez kapcsoltan vagy ennek elhagyásával viselje-e. Ily megállapodás hiányában az örökbefogadott az átruházott családi nevet saját családi nevének elhagyásával volt köteles viselni. Ha az örökbefogadó családi nevét nem ruházta át vagy az örökbefogadó szerződés a névviselésről egyáltalán nem rendelkezett, az örökbefogadott családi neve az örökbefogadással nem változott. ${ }^{90} \mathrm{Ha}$ a saját családi nevérôl az örökbefogadott nem nyilatkozott, akkor nem kötelezte magát arra, hogy saját családi nevét elhagyja. ${ }^{91} \mathrm{Az}$ Mtj. a névváltoztatást diszpozitív szabályokkal rendezte, így tehát a névátruházás nem volt az örökbefogadás elengedhetetlen kelléke. ${ }^{92}$ Emellett a belügyminisztérium - az igazságügyi minisztérium álláspontját elfogadva - évtizedekig nem engedte a névmagyarosítást, ha a név örökbefogadással szereztetett, kivéve, ha ahhoz az örökbefogadó hozzájárult. Mindenkinek érdeke volt az, hogy nevét megváltoztathassa, ha nem magyar hangzású volt, megmagyarosíthassa. (Például vitézzé avatáshoz.) Már akkor megfogalmazódott az a jogszabály-módosító javaslat, hogy a felek az örökbefogadó szerződésben határozottan eldönthessék, hogy az örökbefogadott nevét meg lehet vagy nem lehet megváltoztatni. ${ }^{93}$

A magyar jogban az örökbefogadásnak az örökössé tétel volt a legjelentősebb célja. Az örökbefogadó szerződésben minden feltételtől és korlátozástól mentesen ki kellett jelenteni, hogy az örökbefogadott az örökbefogadó után olyan öröklési jogot nyer, mintha az örökbefogadónak törvényes házasságából származó gyermeke volna, különben a szerződés - az öröklési jog feltételen biztosítása hiányában - nem nyert megerősítést. ${ }^{94} \mathrm{Az}$ örökbefogadással egyoldalú öröklési joga keletkezett az örökbefogadottnak, mivel az örökbefogadó nem szerzett öröklési jogot az örökbefogadott után. A Curia döntésében kimondta, hogy az örökbefogadó szerződésben az örökbefogadott öröklési joga feltételhez nem köthető. ${ }^{55} \mathrm{Az}$ örökbefogadás törvényszerú hatályát az örökbefogadó szerződésben annyiban meg lehetett változtatni, hogy az örökbefogadottnak és ivadékainak az örökbefogadó után ne legyen törvényes öröklési joguk. ${ }^{96}$

\footnotetext{
${ }^{89}$ Mtj. 215. S

${ }^{90} \mathrm{Mtj} .216 .5$

${ }^{91}$ MeSZléNY, Magyar Magánjog I. 707.

${ }^{2}$ Az osztrák polgári törvénykönyv 184. S-a a névváltozást az örökbefogadó szerződésnek a szerződő felek akaratával meg nem változtatható feltételeként szabályozta. Lásd bővebben GAÁR, Az örökbefogadásról 10-11. A névátruházás annyiban esett korlátozás alá, hogy a történelmi és nemzeti családnevek, régi és közismert családnevek átruházása nem kap feltétlenül megerősítést. Az igazságügyi miniszter megkívánhatta, hogy az örökbefogadó szerződésben a névátruházást a felek kapcsolják ki. Lásd bővebben GÁL - NYÁRÁDY, Az örökbefogadás 32.

93 GÁL - NYÁRÁDY, Az örökbefogadás 92.

${ }^{4}$ GAÁR, Az örökbefogadásról 31.

${ }^{95}$ C.I.589/1925.

${ }^{96}$ Mtj. 220-221. \$S
} 
Az örökbefogadás kihatott az örökbefogadott ivadékaira is, azonban nem hatott ki az örökbefogadó rokonaira. A örökbefogadottnak a szerződés megkötésekor már meglevő valamint később született ivadékára az örökbefogadás csak akkor hatott ki, ha az örökbefogadó szerződéshez a már meglevő ivadék is hozzájárult. A hozzájárulást az örökbefogadó szerződésben vagy külön közokiratban kellett kijelenteni vagy közhatóság előtt jegyzőkönyvbe mondani. ${ }^{97}$

Az örökbefogadás legfontosabb joghatásaként megszűnt az örökbefogadott vérszerinti szüleinek szülői hatalma; kiskorú örökbefogadott gyermek esetén a vérszerinti szülő személyes érintkezési joga fennmaradt, azt a szerződésben szabályozhatták is, a gyámhatóság szükség esetén - a gyermek érdekében - korlátozhatta, elvonhatta. A vérszerinti szülő szülői hatalma feléledt, ha az örökbefogadó szülői hatalma megszűnt vagy szünetelt.98



3. ábra: Örökbefogadási pótszerződés 1941-ből (Forrás: GÁL - NYÁRÁDY, Az örökbefogadás 173-174.)

Az örökbefogadott gyermek tartásra volt jogosult (rendes bíróság hatáskörébe tartozott), vérségi összeköttetésen alapuló minden joga fennmaradt (öröklés, tartás és nevelés iránti igénye), mivel az örökbefogadás nem szüntette meg a vérségi kapcsolatot és az ezen alapuló öröklési jogot.99 A joggyakorlat nemcsak azt mondta ki, hogy a törvényes gyermek köteles vagyontalan és keresőképtelen szüleit eltartani, hanem azt is, hogy az örökbefogadott gyermek is köteles örökbefogadó szüleit eltartani, így megeshetett, hogy az örökbefogadott gyermeknek kétfelé kellett tartást fizetnie. ${ }^{100}$ Ugyanakkor az örökbefogadó szerződés nem szüntette meg a vérszerinti szülő tartási kötelezettségét, csak a tartási kötelezettség sorrendjét változtatta meg. Elsősorban az örökbefogadó lett tartásra kötelezve. Ha pedig az örökbefogadási viszony megszűnne vagy a tartást

\footnotetext{
${ }^{97}$ Mtj. 217-218. SS

98 Mtj. 219. $\int$

${ }^{99}$ MESZLÉNY, Magyar Magánjog I. 706.

100 GÁL - NYÁRÁDY, Az örökbefogadás 50-51.
} 
az örökbefogadó nem teljesítené, ez ismét a vérszerinti rokonokra hárul. ${ }^{101} \mathrm{Ha}$ az örökbefogadó szülő tartási kötelezettségét nem teljesítette, akkor az örökbeadó szülő a kiskorú jogán gyermektartási igénnyel léphetett fel az örökbefogadóval szemben. ${ }^{102}$ Az örökbefogadó szülő rendszerint természetben volt köteles és jogosult az eltartás szolgáltatására. ${ }^{103}$

Lehetôség volt arra is, hogy a felek az örökbefogadásból származó jogviszonyukat közös megegyezéssel némely vonatkozásban az alapszerződés rendelkezéseitől eltérô módon szabályozhassák, módosíthassák. Ez az örökbefogadó szerződés jellegénél fogva csak egy újabb szerződéssel (pótszerződés) történhetett, amelynek anyagi tartalmára, kellékeire ugyanazok a szabályok vonatkoztak, mint az alapszerződésre vagy a felbontó szerződésre, azonban az örökbefogadó vagy az örökbefogadott halála után az alapszerződés rendelkezéseit pótszerződéssel módosítani nem lehetett. ${ }^{104}$ Példának okáért előfordulhatott, hogy az alapszerződés nem rendelkezett névátruházásról, de utóbb mégis célszerűnek mutatkozott, hogy az örökbefogadott az örökbefogadó családi nevét viselje vagy éppen ellenkezőleg.

Az örökbefogadást - kétoldalú jogügylet révén, a szerződésre nézve érvényes jogszabályok szerint - egyoldalúan fel nem bonthatták, attól egyik fél sem állhatott el egyoldalú jognyilatkozattal, az ilyen elállásnak jogi hatása nem volt, a szerződésből folyó jogok és kötelezettségek az elállásra tekintet nélkül továbbfolytak. A halál mint szerződést megszüntető ok tekintetében különbséget tettek a között, hogy a szerződő felek egyikének vagy másikának halála a) kormányhatósági megerősítés előtt vagy b) után következett be. Megszűnt továbbá az örökbefogadás, ha azt c) a felek szerződéssel felbontották, vagy ha d) a bíróság ítélettel felbontotta vagy érvénytelenné nyilvánította. Két kivételes megszűnési okot is szabályozott a kódex, amelyekben az örökbefogadás hatálya a törvény erejénél fogva megszűnt. Az egyik esetben az örökbefogadó az örökbefogadás fennállása alatt a törvény tilalma ellenére kötött házasságot az örökbefogadottal vagy annak ivadékával, akire az örökbefogadás kihatott, melynek következtében az örökbefogadás a házasságkötéssel a házastársak között megszűnt, hiszen ugyanazon személyek között egyidejűleg nem állhatott fenn házastársi és szülő-gyermek viszony (az örökbefogadás megszủnése után az örökbefogadott és azok az ivadékai, akikre a megszűnés kihatott, nem viselhették többé az örökbefogadó családi nevét). Nem állt ez a szabály a közösgyermekké-fogadás esetében, ha az örökbefogadást az egyik házastárs halála után szerződéssel bontották fel. ${ }^{105} \mathrm{~A}$ másik kivételes esetben az örökbefogadó saját házasságán kívül született gyermekét fogadta örökbe és azt később törvényesítette, ekkor az örökbefogadás a törvényesítéssel szűnt meg. A gyermek a törvényesítéssel erősebb jogállást nyert és az örökbefogadással szerzett előző jogállása beolvadt az utóbb nyert erősebb, előnyösebb jogállásba, továbbá kettős jogcímen törvényes rokoni kapcsolat nem állhatott fenn szülő és gyermek között. ${ }^{106}$

Az örökbefogadást szerződéssel fel lehetett bontani, melyhez szintén igazságügyi miniszteri megerôsítésre volt szükség, ugyanazon alaki, anyagi kellékek vonatkoztak rá, mint az örökbefogadó

\footnotetext{
101 C.III.623/1929.

102 C.III.2379/1937.

103 C.III. 623/1929.

104 GÁL - NYÁRÁDY, Az örökbefogadás 69-70.

105 Mtj. 224-226. \$S

106 GÁL - NYÁRÁDY, Az örökbefogadás 60-62.
} 
szerződés megkötésére. A felbontó szerződést az örökbefogadónak az örökbefogadottal kellett megkötnie. A megkötött felbontó szerződést jóváhagyás miatt be kellett mutatni a gyámhatóságnak. ${ }^{107}$ A gyámhatóság az összes körülmény figyelembe vétele mellett döntötte el, hogy a felbontás a kiskorú érdekeinek megfelel-e, rá nézve előnyös-e. ${ }^{108}$ Ha a gyámhatóság a felbontó szerződést jóváhagyta, ezt követően az igazságügyi miniszterhez terjesztette fel megerősítés céljából. A miniszter a szerződést, ha annak törvényes feltételei és kellékei fennálltak, megerősítette, leküldte a közvetítő hatósághoz (nagykorúaknál törvényszék, kiskorúaknál árvaszék) azzal az utasítással, hogy füzze a felbontó szerződés példányait az alapszerződés példányaihoz, vezesse rá a felbontó szerződés példányaira a megerôsítő záradékot, a feleknek járó példányokat részükre kézbesíttesse és az anyakönyvben szükségessé vált újabb feljegyzések foganatosítása iránt intézkedjen, ellenkező esetben a megerősítést tagadja meg. ${ }^{109}$ A szerződéshez szükséges volt az örökbefogadott ivadékainak hozzájárulására is, ha rájuk az örökbefogadás kihatott. Közösgyermekké-fogadás esetében az örökbefogadó szerződést - amíg mind a két házastárs élt csak mindkettőjük hozzájárulásával lehetett felbontani. Az egyik házastárs halála után a felbontó szerződést a másik házastárs megköthette oly módon, hogy az örökbefogadás csak vele szemben szűnjön meg. A felbontó szerződéshez sem az örökbefogadó, sem az örökbefogadott házastársának beleegyezésére nem volt szükség. ${ }^{110}$
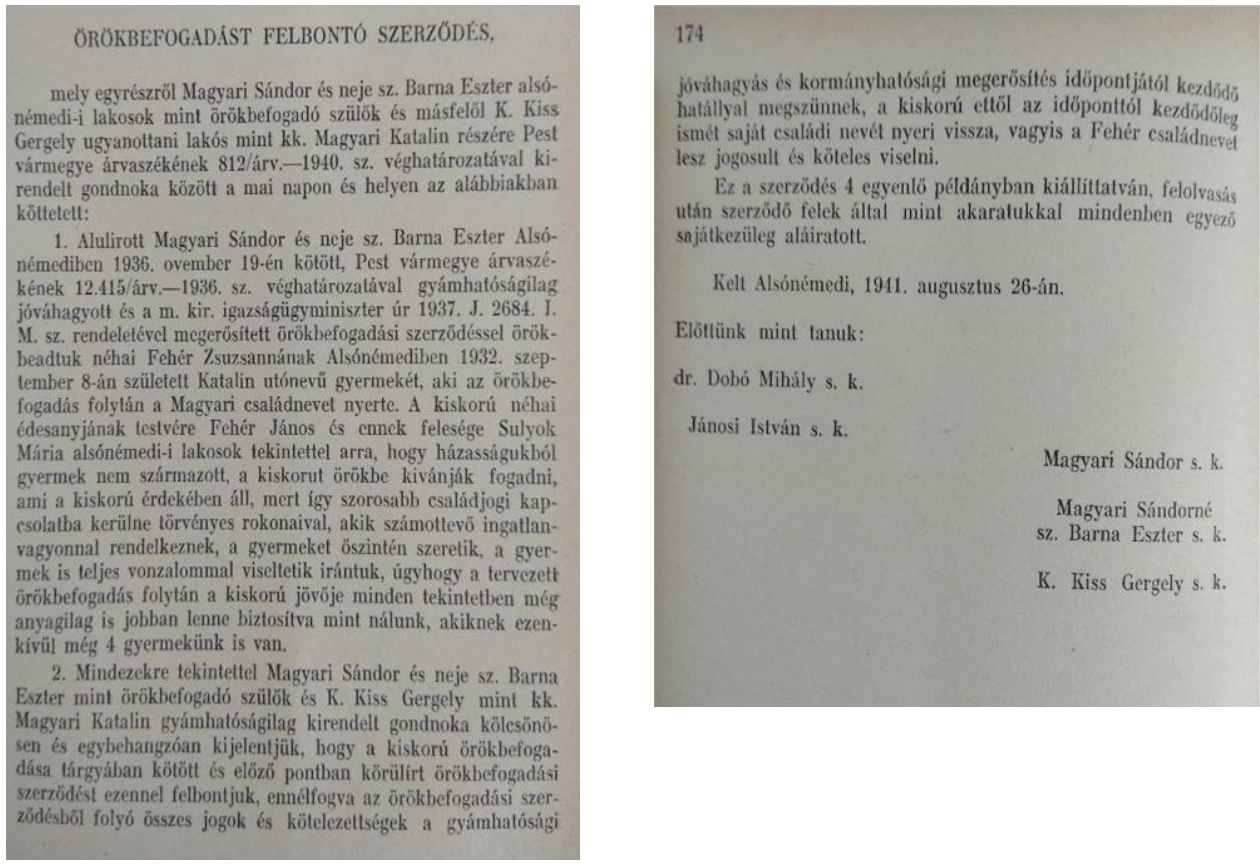

4. ábra: Örökbefogadást felbontó szerződés 1941-ből (Forrás: GÁL - NYÁRÁDY, Az örökbefogadás 173-174.)

\footnotetext{
107 GÁL - NYÁRÁDY, Az örökbefogadás 63.

108 GÁL - NYÁRÁDY, Az örökbefogadás 64.

109 GÁL - NYÁRÁDY, Az örökbefogadás 65.

110 Mtj. 223. \&
} 
Ha az örökbefogadott vagy az örökbefogadó olyan cselekményt követett el, amely miatt a szülő ivadékát vagy az ivadék szülőjét kitagadhatta, vagy pedig ha az örökbefogadott vagy az örökbefogadó az örökbefogadással járó kötelességeit szándékos magaviseletével egyébként oly súlyosan megsértette, hogy emiatt az örökbefogadás fenntartása a másik félre nézve elviselhetetlenné vált, a sértett fél az örökbefogadó szerződés megtámadására vonatkozó szabályoknak megfelelően keresettel kérhette az örökbefogadás bírói felbontását. (Ha az örökbefogadó vagy az örökbefogadott meghalt vagy a vétkes cselekményt megbocsátották, akkor felbontásnak helye nem volt). Az örökbefogadás a felbontó ítélet jogerőre emelkedésének napján a felek között megszűnt. A bíróság az örökbefogadást a felbontó ítéletben bármelyik fél kérelmére az örökbefogadott ivadékaira nézve is felbontottnak nyilváníthatta, ha ez a körülmények szerint indokolt volt.

A Curia számos döntésében mérlegelte, hogy a szerződő felek magatartásai mely esetekben minősülnek egyik vagy másik félre nézve elviselhetetlen körülménynek az örökbefogadás felbontásához. A testület egyik döntésében kimondta, hogy a szülő részéről a házi fegyelem gyakorlása közben a kiskorú gyermekkel szemben alkalmazott testi fenyítés mindaddig, amíg annak egészségét vagy testi épségét súlyosan nem veszélyeztette, jogtalan cselekménynek, tehát támadásnak még akkor sem volt minősíthetô, ha arra komoly ok és szükség nem is volt. A Curia ugyancsak nem fogadta el az örökbefogadó által a szerződés felbontása iránt indított keresetével szemben az örökbefogadott gyermeknek azt az előadását, hogy nem lépett fel támadólag, hanem csak védekezésül taszította el magától az örökbefogadót és ily módon okozott neki testi sértést. Indokolásában kifejtette, hogy a szülői fenyítéssel szemben - amíg az a megengedhetőség határát túl nem lépi - a gyermek részérôl jogos védelemnek helye nincs. ${ }^{111}$

Az örökbefogadottnak az örökbefogadóval való közös háztartásból történő elköltözése önmagában az örökbefogadó szerződést nem tette céljavesztetté, ${ }^{112}$ mivel az örökbefogadó apa a kiskorúval szemben apai hatalmának az árvaszék útján bármikor érvényt szerezhetett. Azonban előfordulhattak olyan körülmények is, amelyekkel kapcsolatban a családi otthon elhagyása és visszatérésének makacs megtagadása az örökbefogadási viszonyt lehetetlenné és egyben elviselhetetlenné tette. ${ }^{113} \mathrm{Az}$ örökbefogadás felbonthatósága mellett foglalt állást a Curia abban az esetben, amikor az örökbefogadó földműves szülők örökbefogadott gyermeke nem volt hajlandó családtagként a gazdaságban tevékenykedni, hanem elfogadható indok nélkül idegen községbe költözött. ${ }^{114}$ A családi otthonnak az örökbefogadó szülő akarata ellenére történő elhagyása és visszatérésének indokolatlan megtagadása a szülői tisztelet és engedelmesség súlyos megsértésének minősült, mely a családi életközösséget szüntette meg.

Amennyiben az örökbefogadó szerződés kifejezetten rendelkezett arról, hogy az örökbefogadott munkaerejét az örökbefogadó gazdaságában fejtse ki, azonban ezt a kötelezettségét jogos indok nélkül megtagadta - feltéve, hogy az örökbefogadó felhívta az örökbefogadottat kötelezettsége teljesítésére - a szerződés felbontásának alapos okául szolgálhatott. ${ }^{115}$ Amennyiben

\footnotetext{
111 C.III.5248/1938.

112 C.III.5341/1930.

113 C.III.3920/1938.

114 C.III.1930/1926., C.III.3511/1929.

115 C.III.5769/1936.
} 
a falusi gazda legénysorban lévő örökbefogadott gyermeke éjjelente kimaradt - nem kocsmázás, dorbézolás miatt, hanem csak, mint afféle fiatalember - amúgy nappal apja gazdaságában földműves legényként dolgozott, a kimaradásból folyóan az örökbefogadót kár nem érte, így az örökbefogadott munkája elvégzését, engedelmességét meg nem tagadta, súlyos kötelezettségszegés nem volt megállapítható terhére. ${ }^{116}$

Az örökbefogadott gyermeknek az a kijelentése, hogy az örökbefogadó anya nevelt fiával szerelmi viszonyt folytat, az örökbefogadó szülő iránt tartozó gyermeki tisztelet és köteles megbecsülés olyan durva és súlyos megsértésének minősült, hogy ennek folytán az örökbefogadó anya jogosult volt az örökbefogadó szerződést felbontani. ${ }^{117} \mathrm{~A}$ hamis vádaskodásnak abban a kirívó esetében, amikor az örökbefogadott gyermek saját édesanyját, az örökbefogadó apa feleségét bosszúból azzal vádolta meg, hogy vele viszonya van, helye volt az örökbefogadó szerződés megtámadása iránti keresetnek. ${ }^{118}$ Felbontható volt a szerződés az örökbefogadó szülő azon magatartása miatt is, hogy az örökbefogadott fiát és annak feleségét ok nélkül azzal gyanúsította, hogy ôt meglopták, az örökbefogadott fiát hitvány gazembernek, feleségét rossz életűnek nevezte és felszólította őket, hogy 24 órán belül takarodjanak a házból..19 Becsületsértő kifejezések használata az örökbefogadó szerződés felbontására alkalmas oknak nem minősült akkor, ha a sértő fél olyan tényeket bizonyított, melyekből megállapítható volt, hogy magatartását a másik félre visszavezethető erős felindulás váltotta ki, amelynél fogva a sértések terhére be nem számíthatóak. Ennek a körülménynek a megítélésénél meghatározó szerepe volt az érdekeltek társadalmi állásának, múveltségi fokának, valamint annak is, ha az elkövetett sértés a másik fél részérôl elkövetett sértés azonnali viszonzása volt-e. ${ }^{120}$

\section{Az örökbefogadás gyakorlata Pécs város árvaszékének iratai alapján (1872 - 1923) ${ }^{121}$}

A vizsgált örökbefogadó szerződések többsége azzal indokolta a gyermek érdekében álló örökbefogadást, hogy annak létrejöttével a gyermek családi jogállása rendeződik (tehát törvénytelen származása megszűnik), örökösödési jogot (beleértve a kötelesrészt is), atyai hatalmat kap és jogosult viselni az örökbefogadó családnevét. A szerződő felek szegény sorsára tekintettel a törvény kivételt engedett az örökbefogadó szerződés írásba foglalása alól, mert az az árvaszék előadója vagy az árvaszék által megbízott szolgabíró előtt szóban is megköthető volt. Ezzel a lehetőséggel gyakran éltek a szegény körülmények között élő családok, akik szegénységi bizonyítvánnyal igazolták állításukat és kérték, hogy a szükséges okmányokat az árvaszék szerezze be. ${ }^{122}$ Az örökbefogadó szerződésbe belefoglalták mindazon jogokat (öröklési jog, névátruházás stb.), amelyeket az örökbefogadó az örökbefogadottra és utóbbinak törvényes képviselője az örökbefogadóra (atyai hatalom, gyámság) átruházott. Kivétel nélkül minden vizsgált örökbefogadó szerződés rendelkezett arról, hogy az örökbefogadott addig viselt családnevét hagyja el és viselje az örökbefogadó atyja

\footnotetext{
116 C.III.4940/1932.

117 C.II.181/1936.

118 C.III.6137/1929.

119 C.III.3240/1937.

120 C.III.91/1933.

${ }^{121}$ MNL BML IV. 1409.b. 687-1905, 186-1906, II-89-1899, 186-1906

122 MNL BML IV. 1409.b. 687-1905
} 
családnevét. Az 1872 és 1923 közötti évekből fennmaradt 118 örökbefogadási ügy közül öt esetben találkoztam azzal, hogy az igazságügyi miniszter megtagadta az örökbefogadó szerződés megerősítését. Három esetben úgy szólt az örökbefogadó szerződés, hogy az „örökbefogadó átvállalja az örökebe fogadandóval szemben mindazon jogokat, melyek az atyát a törvény szerint gyermekével szemben megilletik".

A vérszerinti szülő nem ruházhatta át az örökbefogadóra azon jogait, amelyet ôt a gyermekével szemben megillették, (örökbefogadó anya csak azon jogáról mondhat le, amelyet ôt természetes és törvényes gyámsága alapján megillette, például a törvényes örökösödési jog). ${ }^{123}$ Egy másik esetben a gyermek törvénytelen származásúként volt anyakönyvezve, annak ellenére, hogy házasságban született, így házassági vélelem okán, törvényes gyermekként az örökbefogadás érvényesen nem jöhetett volna létre. ${ }^{124}$ Egy aktában az örökbefogadást felbontó szerződés megerősítését azért tagadta meg az igazságügyi miniszter, mivel az eljárás során a kiskorú részére nem rendeltek gondnokot, ugyanis az örökbefogadó atya saját személyében nem bonthatta fel a szerződést, neki a gyermek gyámjával kellett volna megkötnie a felbontó szerződést. Az egyik örökbefogadó szerződés hiányos volt a tekintetben is, hogy az „örökbefogadandó a rá átrubázni szándékolt családnevet saját születési családnevéhez. kapcsolva vagy ennek elhagyása mellett köteles és jogosult-e a jövöre nézve viselni". ${ }^{125} \mathrm{Az}$ igazságügyi miniszter az örökbefogadó szerződést megtagadó iratán konkrét utasításokkal látta el az árvaszékeket, törvényszékeket abban az esetben, amikor a megtagadás alapjául szolgáló ok orvosolható volt.

Az 1872 és 1923 közötti időszakban Pécs város árvaszékének irataiban összesen 105 iratjegyzékben leltem örökbefogadás tárgyában felvett jegyzőkönyvre, örökbefogadó szerződésre vagy ezek mindegyikére, melyekben összesen 118 gyermek került örökbefogadó szülő(k)höz. 118 gyermek közül 9 házasságból származott, 42 pedig törvénytelen gyermek volt, a fennmaradó 67 gyermek származására utaló adatot nem találtam. Az örökbefogadások többsége közös gyermekkéfogadás volt: a férj fogadta örökbe felesége házasságon kívül született gyermekét. A fenti adatok a precíz, kitartó levéltári kutatás ellenére is csak tájékoztató jellegűek, ugyanis több aktában nem találtam információt a fenti szempontokra. Az 1872 és 1923 között kötött 105 örökbefogadás közös jellemzői a következők:

1. az örökbefogadás gyakori oka, hogy a szülő(k) elhunyt(ak), vagy a gyermeket az édesanyja egyedül eltartani nem volt képes vagy az örökbefogadók gyermektelenek;

2. az örökbefogadás okaként szerepel a szerződésekben az a fordulat, hogy az örökbefogadás a gyermekre nézve anyagi, erkölcsi szempontból előnyös;

3. az örökbefogadások többsége közös gyermekké-fogadás volt;

4. az örökbefogadásról szóló jegyzőkönyv vagy az örökbefogadó szerződés kifejezetten tartalmazta az örökbefogadott gyermeket megillető örökösödési jogot az örökbefogadó szülő(k) után;

5. az örökbefogadott gyermek kivétel nélkül felvette az örökbefogadó szülő családnevét;

6. az örökbefogadó szülők szerény anyagi helyzete miatt, járatlanságukra tekintettel árvaszék előtt mondták jegyzőkönyvbe örökbefogadás iránti kérelmüket.

\footnotetext{
123 MNL BML IV. 1409.b. 186-1906

${ }^{124}$ MNL BML IV. 1409.b. II-89-1899

125 MNL BML IV. 1409.b. 186-1906
} 
Az örökbefogadás jelentősége a két világháború között megkérdőjelezhetetlen volt mind a gyermekek, mind az örökbefogadó szülők részérôl. A háború folytán apa nélkül maradt családok gyermeküket eltartani nem tudták, az árvák állami gondozásba kerültek, a családi otthon melegét az örökbefogadás teremthette meg számukra újra, ahogy a gyermektelen családok részére is.

\section{Felhasznált források és irodalom}

Magyarország magánjogi törvénykönyvének a m. kir. Igazságügyminiszter által az országgyülés elé terjesztett törvényjavaslata. Budapest $1928=$ Mtj.

1946. évi XXIX. törvénycikk indokolása a házasságon kívül született gyermek jogállásáról https://net.jogtar.hu/ezerev-torveny?docid=94600029.TVI\&searchUrl=/ezer-ev-torvenyei\%3Fpagenum\%3D51

(letöltve: 2018. 07. 01.) = Indokolás 1946

BACSÓ Jenő: Az örökbefogadás. Jogtudományi Közlöny 1981/7. 609-616.

GAÁr Vilmos: Az örökbefogadásról. Budapest 1898

GÁL Dezső - NYÁRÁDY László: Az örökbefogadás, különös tekintettel a gyakorlati eljárásra. Budapest 1941

Herger Csabáné: A nôvételtől az állami anyakönyvvezetőig. Budapest - Pécs 2006

HERGER Csabáné: A modern magyar házassági vagyonjog kialakulása és rendszere a német jogfejlődés tükrében. Passau 2017

KŐRÖS András (szerk.): A családjog kézikönyve I. kötet. Budapest 2007

MESZLÉNY Artúr: Magyar Magánjog I. Budapest 1931

NizSALOVSZKY Endre: A család jogi rendjének alapjai. Budapest 1963

WEISS Emília: Az örökbefogadás néhány társadalmi és jogi kérdése. Magyar Tudomány 1997/2. 180-192. 